ZBigniew WoJCIECHOWSKI, JANUSZ MARKOWSKi, TOMASZ JANISZEWSKI \& JANUSZ HEJDUK

Department of Teacher Training and Biodiversity Studies, University of Łódź, Banacha 1/3, 90-237 Łódź, Poland, zbig@biol.uni.lodz.pl

\title{
30-YEAR-LONG CHANGES IN TERRESTRIAL VERTEBRATE FAUNA OF NIEBIESKIE ŹRÓDŁA (BLUE SPRINGS) NATURE RESERVE IN TOMASZÓW MAZOWIECKI, CENTRAL POLAND
}

\begin{abstract}
The article focuses on changes in terrestrial vertebrate fauna of Niebieskie Źródła (Blue Springs) Nature Reserve that occurred between two censuses carried out in the area. The first census was carried out in the period of 1968-1970, and the second census in the period of 1998-1999. In 1998-1999 the occurrence of four species of amphibians, 41 of birds and 15 of mammals was recorded. In comparison with investigations from 1968-1970 two species of amphibians, two species of mammals, and nine species of birds were found to have disappeared from the reserve. In the census carried out in 1998 and 1999 we recorded 22 new species of vertebrates: one new species of amphibian, five species of mammals, and 16 species of birds. The recent observations showed a decline in the abundance of amphibian species in the reserve, especially in the closest vicinity to the urban development around the city of Tomaszów Mazowiecki. The quantitative data on birds showed an increase in the numbers and abundance, which was mainly pronounced in the group of forest species, especially cavity and shrub nesters. We suggest that these changes are directly related to the succession of forest vegetation and its developing vertical structure, as well as to an increase in the forestation of the reserve area.
\end{abstract}

Key words: diversity, species richness, terrestrial vertebrate community, bird community changes, nature reserve 


\section{INTRODUCTION}

A nature reserve, by definition, represents entire environmental variation and should be set up in response to certain scientific criteria. Following these assumptions, the regional complementary and representative reserve network should be formed (BENNETT 1994). In practice most reserves have been formed on the basis of the richest-in-species areas, however, other criteria, such as aesthetic or even socio-economic are also taken into consideration (EMNEBORG, GÖTMARK 2000; RODRIGUES et al. 2004). In human-dominated environments nature reserves have played an important role in the conservation of biodiversity (FORMANN 1995; Margules, Pressey 2000).

The Łódź Voivodeship $\left(18.219 \mathrm{~km}^{2}\right)$, Central Poland, is the area that is heavily transformed and degraded by human activity. This is confirmed by the lowest index of forestation in the country (20.6\%) and by large area of degradation due to the strip mines and electricity power station situated in Bełchatów Industrial Region. Despite the circumstances, there are 89 nature reserves in Lódź Voivodeship, covering a total area of 7405.06 ha, which constitute $0.4 \%$ of the Voivodeship (WĘŻYK 2008).

Niebieskie Źródła Nature Reserve (28.77 ha), situated within the town of Tomaszów Mazowiecki, was created in 1961 to protect a rare geological phenomenon in Central Poland, known as limnocrenic springs and their picturesque watershed (MOwSZOWICZ, OLACZEK 1961). The first faunistic data on terrestrial vertebrates of Niebieskie Źródła, although very scarce and imprecise or sometimes even false, were presented in the documentation of the reserve and in the first popular science publications (MowszOwICZ, OLACZEK 1961, 1965). In 1967-1970 there was an inventory of aquatic invertebrates, fishes and one terrestrial insect family Syrphidae (Diptera) (WOJTAS, SOSZYŃSKI 1972), as well as of terrestrial vertebrates in the area of the reserve and its closest vicinity was carried out. The presence of seven amphibian species (TRANDA, CICHOWICZ 1972), 35 breeding bird species (MARKOWSKI, WOJCIECHOWSKI 1972) and 12 mammal species (BARTOSZ, MARKOWSKI 1972) was then recorded. The study showed no distinction in the fauna composition but specificity in the community of limnological invertebrates 
(OLACZEK, TRANDA 1990) and indicated some characteristic adaptations in their biology, mainly prolongation of life cycles caused by the stable water temperature of about $9^{\circ} \mathrm{C}$ (TABACKI 1972; TOMASZEWSKI 1972). Irregular ornithological observations were carried out and published by MARKOWSKI (1982) and SOSNOWSKI $(1994,1995)$ in the following years. Complex zoological investigations that were conducted in 1997-1998 covered various groups of invertebrates (TOŃCZYK et al. 2000).

The aim of this study is to examine the changes in the composition of terrestrial vertebrate fauna of the reserve in relation to the succession of plant associations and urbanization pressure.

\section{MATERIALS AND METHODS}

\subsection{Study area}

The total area of the reserve is 28.77 ha, including 22.57 ha of forest, 5.72 ha of canals and flooded areas together with the outlet section of the stream, and 0.48 ha of roads. In the flooded areas there are three larger and six smaller islands of the total area of 4.08 ha. On the flat banks of the canals and on the islands, an alderwood (Alnetum glutinosae) and fragments of alder-ash carr (Fraxineto-Alnetum) are present. These associations occupy a total of $8.22 \mathrm{ha}$. The tree stands are formed by 40-60-year old Black Alder (Alnus glutinosa) trees; small fragments are 60-80 years old. In the undergrowth layer the European Spindle (Euonymus europeus), Alder Buckthorn (Rhamnus frangula), and Willow (Salix sp.) are recorded. The southeastern bank and interior of two of the islands are overgrown by fresh pine forest (a total of $10.55 \mathrm{ha}$ ), where 40-45-year old Scots Pine (Pinus silvestris) trees dominate. Higher level of the flooded area is occupied by an over 100-year-old pine stand. In its middle part, after an extirpation of trees in 1974, Pine and Birch (Betula sp.) trees were planted over an area of 1.65 ha. Some other islands and the western bank are occupied by fresh mixed forest (a total of 2.70 ha). This stand is dominated by 40 years old pine trees with contributions of Oak (Quercus sp.), Linden (Tilia sp.), Larch (Larix sp.), Sycamore Maple (Acer pseudoplatanus), Northern Maple (Acer platanoides) and Poplar (Populus sp.). Between the road to the Ludwików 
Settlement and the eastern bank 25-30-year old planted alder and birch trees with brushwood of alder buckthorn and European Rowan (Sorbus aucuparia) occur.

In comparison with the investigations carried out in the period of 1967-1970 essential changes have occurred in the structure of forest associations due to the aging of tree stands and development of layer structure in the tree stratum, bushes, and creeper vegetation. Besides, the afforested area has increased by $4 \%$. Formally only one section (a meadow -0.7 ha of the area) has been completely planted with trees, but in practice several forest species (Oak, Lime, Sycamore Maple, Northern Maple) were planted in some other parts of the reserve. After the accidental extirpation of 1.65 ha of fresh forest in the early 1970s, a fragment of the respective area was afforested with pine and birch trees. In the years 1994-1995 hydrotechnical works were carried out to remove the organic sediments from the main water basin and canals by the method of hydraulic dredging. The patches of Glyceria aquatica and others patches of reeds, as well as plants growing on the shoreline were removed. The shoreline was straightened and strengthened by the Willow.

\subsection{Samples}

\subsubsection{Amphibians}

Material was collected from April to August 1998 while penetrating the whole area of the reserve and its closest vicinity. Amphibians were captured and released after marking. Only the records from the area of the reserve were used in the comparisons.

\subsubsection{Birds}

A combined cartographic method was used for the qualitative and quantitative assessment of nesting avifauna of the reserve (TOMIAŁOJĆ 1980). In the case of Mallard Anas platyrhynchos and Tufted Duck Aythya fuligula estimation methods followed the instructions of BOROWIEC et al. (1981). Estimates of the abundance of the avifauna in the whole area of the reserve were done during nine bird censuses carried out at 10 to 14 day intervals between 9 April and 23 July 1998. The qualitative changes in bird assemblages were estimated by the fauna turnover 
index: $\mathrm{T}=(\mathrm{C}+\mathrm{E}) /\left(\mathrm{S}_{1}+\mathrm{S}_{2}\right)$ (DiAmOND, MAY 1997), where: $\mathrm{C}$ is the number of colonized species, $E$ is the number of extinct species, $S_{1}$ and $S_{2}$ are the numbers of species in the particular samples. We also calculated bird species diversity (using the Shannon-Wiener index H'), the evenness index (J'), and total biomass (i.e. the sum of body weight of breeding pairs). The differences between $H^{\prime}$ indices were tested by $\mathrm{t}^{0}$ formula presented by HUTCHESON (1970). Values of body weights characteristic for different avian species followed the estimates given by SOKOŁOWSKI (1972). Bird species were categorized according to ecological guild nesting substrates: ground nesters, shrub nesters, tree nesters, cavity nesters (FULLER 1995; JOKIMÄKI, HUHTA 1996); and habitat preferences: edge of the forest or open habitat (treated jointly), and interior of the forest (HAAPANEN 1965; GROMADZKI 1970; TOMIAŁOJĆ et al. 1981). The differences in abundance of functional guild classification and forest habitat preferences were tested by nonparametric tests: $\chi^{2}$ and Wilcoxon signed-rank test.

\subsubsection{Mammals}

The samples of micromammalia were taken overnight. There were two sampling periods: on the night of 14-15 October 1997 (120 trap-nights) and 10-11 September 1998 (120 trap-nights), three lines of 40 live- and snap-traps placed in 10 $\mathrm{m}$ intervals. Trap lines were distributed on two islands and in the western and southern parts of the reserve covering the most typical plant associations (alderwoods, mixed forest, pine forest). Besides, on the night of 3-4 September 1999 a sampling of bats in mist-nets was carried out. Additionally, all traits of mammal presence (bites, trails, excrements) were recorded. For comparison with 1968-1970 period the index of trappability was calculated $\left(\mathrm{IP}=\mathrm{n}_{\mathrm{i}} / \mathrm{n}_{\mathrm{t}}\right.$, where $\mathrm{n}_{\mathrm{i}}$ - number of specimens of given species captured, $\mathrm{n}_{\mathrm{t}}$ - number of traps).

\section{RESULTS}

\subsection{Amphibians}

During the recent studies four species of anura (29 specimens) were recorded, including Green Toad (Bufo viridis) - a new species (Table 1). To show 
the trends in the abundance we decided to present the number of anuran species visually recorded within the area of the reserve and compare them with earlier data, when all seen individuals were caught for parasitological investigation (CICHOWICZ, ŻUCHOWSKA 1972).

Table 1. The number of amphibians caught for parasitological investigation in 19681970 period (CICHOWICZ, ŻUChOWSKA 1972; TrandA, Cichowicz 1972) and observed in 1997-1998 period.

\begin{tabular}{lcc}
\hline Species & 1968-1970 & 1997-1998 \\
\hline Rana esculenta & 4 & - \\
Rana lessonae & 1 & - \\
Rana temporaria & 17 & 8 \\
Rana arvalis & 20 & 9 \\
Bufo bufo & 10 & 6 \\
Bufo viridis & - & 1 \\
\hline Total & 52 & 24 \\
\hline
\end{tabular}

Common Toad (Bufo bufo): in the breeding season (April 1998) single specimens were recorded in the outflow part of the flooded area and in the outflow stream. Migrating individuals were recorded several times in various parts of the reserve (from April to July 1998).

European Green Toad (Bufo viridis) occurred in the closest vicinity of the reserve. One dead specimen for the first time was noticed on 12 May 1998 on the road leading to the Ludwików Settlement.

Common Frog (Rana temporaria) was recorded twice in the outlet part of the flooded area in April 1988. Migrating specimens were observed several times in the western part of the reserve between May and July (totally eight individuals were recorded). 
Marsh Frog (Rana arvalis) was observed several times (from May to July 1998), most frequently in the western part of the reserve and on the islands (totally nine individuals were recorded).

Additionally, a small reservoir in the close vicinity of the western border of the reserve and a series of oxbow lakes on the right side of the Pilica River floodplain were controlled. In total, eight amphibian species including Common Water Frog (Rana esculenta), Pool Frog (Rana lessonae), Smooth Newt (Triturus vulgaris), and Great-crested Newt (Tristurus cristatus), were recorded. Except for the European Green Toad, all above listed species were not numerous.

\subsection{Birds}

The number of species of breeding birds recorded in 1997 was 41. Two species of waterfowl (Mallard and Tufted Duck) were found to nest in the reserve, in the abundance of 12 and 11 pairs, respectively. The abundance, density and domination of the remaining 37 species are presented in Table 2, along with similar data for 1968-1970 (MARKOWSKI, WOJCIECHOWSKI 1972). The data from 19681970 were not collected according to the requirements of the cartographic methods and detailed number of breeding pairs was not quantified for Starling (Sturnus vulgaris) and Tree Sparrow (Passer montanus). A relative scale was used instead. Nevertheless, the field notes from these years (JM and ZW) allowed precise estimation of nesting pair abundance. The calculated biodiversity indices and turnover index are presented in Table 3. An increase in the species richness and important changes in bird assemblages (disappearance of nine and appearance of 16 new species) were recorded, what was supported by the high value of turnover index $\mathrm{T}=0.36$ (Table 3).

Total abundance was almost three times higher in the later study period, and the difference was significant $\left(\chi_{0}^{2}=75.65, \mathrm{df}=1, \mathrm{P}<0.001\right)$. With regard to the biotope preferences, there was an almost 5 -fold increase in the abundance of interior forest bird species, which changed from 44 pairs in 1968 to 209 pairs in 1998. There was an increase in the frequency of this group from $51.1 \%$ to $85.5 \%$. Simultaneously, there was a decrease in the number of open habitat or forest-edge bird species from 
39 pairs in 1968 to 35 pairs in 1998 and a pronounced decrease in the frequency of this group from $45.3 \%$ to $14.2 \%$ (Table 4 ). The differences in the abundance of both groups were significant $\left(\chi_{0}^{2}=42.29, \mathrm{df}=1, \mathrm{P}<0.001\right)$. Apart from that, significant differences were shown for interior forest bird species, as well as their abundance (Wilcoxon-test $Z^{0}=3.07, p=0.002, n=15$ ), density (Wilcoxon-test $Z^{0}=3.11, p=0.002$, $\mathrm{n}=15$ ), and biomass (Wilcoxon-test $Z^{0}=2.97, \mathrm{p}=0.003, \mathrm{n}=15$ ) were higher in 1998 .

There was a slight decrease in the following edge species: Icterine Warbler (Hippolais icterina), Golden Oriole (Oriolus oriolus) and Serin (Serinus serinus). Other edge species, such as Whitethroat (Sylvia communis), Tree Sparrow (Passer montanus) and Yellowhammer (Emberiza citrinella) and one species related to open habitats - Crested Lark (Galerida cristata), completely retreated from the reserve (Table 2).

Several forest species, such as: Pied Flycatcher (Ficedula hypoleuca), Blackbird (Turdus merula), Song Trush (Turdus philomelos), Wood Warbler (Phylloscopus sibilatrix), Nuthatch (Sitta europaea), Wren (Troglodytes troglodytes), Coal Tit (Periparus ater) and Hawfinch (Coccothraustes coccothraustes) appeared in the reserve, and several other increased their numbers, i.e. Great Tit (Parus major), Blue Tit (Cyanistes caeruleus), Blackcap (Sylvia atricapilla), Chiffchaff (Phylloscopus collybita), Robin (Erithacus rubecula), Chaffinch (Fringilla coelebs), Jay (Garrulus glandarius) (Table 2).

In the respective comparison of density, 2.8 times higher values were obtained for the later study period (Table 2). Particularly interesting is almost 4.5fold increase in the group of cavity or semicavity nester birds, 4-fold increase in the shrub nester species and about 2- and 2.5-fold increase in tree and ground nester groups (Table 4).

The frequency of shrub nesters increased between both study periods from $2.3 \%$ to $13.5 \%$ and their biomass increased from 0.11 to $0.74 \mathrm{~kg} / 10$ ha. The same trend was recorded in semicavity and cavity nesters. There was an increase from $29.5 \%$ to $39.5 \%$ in frequency and from 0.85 to $1.63 \mathrm{~kg} / 10$ ha in their biomass. A decrease in frequency and biomass was recorded in two other guild nester groups (Table 4). Only the cavity and semicavity nesters were more abundant (Wilcoxon- 
Table 2. Selected characteristics of breeding bird community in the Niebieskie Źródła Nature Reserve in years 1968-1970 and in 1998. Asterisk indicates bird species breeding at the border of the reserve

\begin{tabular}{|c|c|c|c|c|c|c|}
\hline \multirow[b]{2}{*}{ Species } & \multicolumn{3}{|c|}{$1968-1970$} & \multicolumn{3}{|c|}{1998} \\
\hline & $\begin{array}{l}\text { Number } \\
\text { of pairs }\end{array}$ & $\begin{array}{l}\text { Density of } \\
\text { pairs/10 ha }\end{array}$ & $\begin{array}{c}\text { Dominance } \\
(\%)\end{array}$ & $\begin{array}{l}\text { Number } \\
\text { of pairs }\end{array}$ & $\begin{array}{l}\text { Density of } \\
\text { pairs/10ha }\end{array}$ & $\begin{array}{c}\text { Dominance } \\
(\%)\end{array}$ \\
\hline Parus major & 3 & 1.04 & 3.48 & 34 & 11.82 & 13.9 \\
\hline Cyanistes caeruleus & 1 & 0.35 & 1.16 & 21 & 7.30 & 8.6 \\
\hline Turdus pilaris & 2 & 0.70 & 2.32 & 19 & 6.60 & 7.8 \\
\hline Phylloscopus collybita & 4 & 1.39 & 4.65 & 19 & 6.60 & 7.8 \\
\hline Fringilla coelebs & 6 & 2.09 & 6.97 & 15 & 5.21 & 6.2 \\
\hline Phylloscopus trochilus & 6 & 2.09 & 6.97 & 14 & 4.86 & 5.8 \\
\hline Sylvia atricapilla & 4 & 1.39 & 4.65 & 13 & 4.52 & 5.4 \\
\hline Sturnus vulgaris & 10 & 3.46 & 11.63 & 13 & 4.52 & 5.4 \\
\hline Erithacus rubecula & 6 & 2.09 & 6.97 & 10 & 3.46 & 4.2 \\
\hline Columba palumbus & 2 & 0.70 & 2.32 & 8 & 2.76 & 3.4 \\
\hline Ficedula hypoleuca & - & - & - & 7 & 2.43 & 2.9 \\
\hline Turdus merula & - & - & - & 6 & 2.09 & 2.5 \\
\hline Phylloscopus sibilatrix & - & - & - & 5 & 1.74 & 2 \\
\hline Sitta europaea & - & - & - & 5 & 1.74 & 2 \\
\hline Troglodytes troglodytes & - & - & - & 5 & 1.74 & 2 \\
\hline Luscinia luscinia & 2 & 0.70 & 2.32 & 4 & 1.39 & 1.6 \\
\hline Garrulus glandarius & 1 & 0.35 & 1.16 & 4 & 1.39 & 1.6 \\
\hline Muscicapa striata & 1 & 0.35 & 1.16 & 4 & 1.39 & 1.6 \\
\hline Certhia brachydactyla & 1 & 0.35 & 1.16 & 3 & 1.04 & 1.2 \\
\hline Coccothraustes coccothraustes & - & - & - & 3 & 1.04 & 1.2 \\
\hline Hippolais icterina & 4 & 1.39 & 4.65 & 3 & 1.04 & 1.2 \\
\hline Pica pica & 2 & 0.7 & 2.32 & 3 & 1.04 & 1.2 \\
\hline Certhia familiaris & 1 & 0.35 & 1.16 & 2 & 0.7 & 0.8 \\
\hline Chloris chloris & 4 & 1.39 & 4.65 & 2 & 0.7 & 0.8 \\
\hline Dendrocopos minor & - & - & - & 2 & 0.7 & 0.8 \\
\hline Oriolus oriolus & 3 & 1.04 & 4.48 & 2 & 0.7 & 0.8 \\
\hline Lophophanes cristatus & - & - & - & 2 & 0.7 & 0.8 \\
\hline Poecile montanus & 2 & 0.7 & 2.32 & 2 & 0.7 & 0.8 \\
\hline Prunella modularis & - & - & - & 2 & 0.7 & 0.8 \\
\hline Serinus serinus & 3 & 1.04 & 4.48 & 2 & 0.7 & 0.8 \\
\hline Sylvia borin & - & - & - & 2 & 0.7 & 0.8 \\
\hline Turdus philomelos & - & - & - & 2 & 0.7 & 0.8 \\
\hline Carduelis carduelis & - & - & - & 2 & 0.7 & 0.8 \\
\hline Corvus corone & 1 & 0.35 & 1.16 & 1 & 0.35 & 0.4 \\
\hline Dendrocopos major & 1 & 0.35 & 1.16 & 1 & 0.35 & 0.4 \\
\hline Periparus ater & - & - & - & 1 & 0.35 & 0.4 \\
\hline Sylvia curruca & - & - & - & 1 & 0.35 & 0.4 \\
\hline Phoenicurus phoenicurus & - & - & - & $*$ & - & - \\
\hline Emberiza citrinella & 3 & 1.04 & 4.48 & $*$ & - & - \\
\hline Streptopelia turtur & 1 & 0.35 & 1.16 & - & - & - \\
\hline Picus viridis & 1 & 0.35 & 1.16 & - & - & - \\
\hline Sylvia communis & 2 & 0.70 & 2.32 & - & - & - \\
\hline Motacilla alba & 2 & 0.70 & 2.32 & - & - & - \\
\hline Passer montanus & 4 & 1.39 & 4.65 & - & - & - \\
\hline Galerida cristata & 1 & 0.35 & 1.16 & - & - & - \\
\hline Acrocephalus arundinaceus & 1 & 0.35 & 1.16 & - & - & - \\
\hline Acrocephalus palustris & 1 & 0.35 & 1.16 & - & - & - \\
\hline Anas platyrhynchos & $6-7$ & & & 12 & & \\
\hline Aythya fuligula & - & & & 11 & & \\
\hline Gallinula chloropus & 2 & & & - & & \\
\hline Total & 86 & 30.06 & 99.94 & 244 & 84.86 & 99.9 \\
\hline Total number of species & 34 & & & 41 & & \\
\hline
\end{tabular}


test $Z^{0}=3.37, p=0.018, n=9$ ), had higher density (Wilcoxon-test $Z^{0}=3.37, p=0.018$, $n=9$ ), and biomass (Wilcoxon-test $Z^{0}=3.37, p=0.018, n=9$ ) in the second period. The differences in the frequency were not significant. Also indices of biological diversity $\left(\mathrm{H}^{\prime}\right)$ did not differ $\left(\mathrm{t}^{0}=0.24, \mathrm{p}=0.82, \mathrm{df}=226\right)$.

Table 3. Comparison of diversity indices of birds between two periods of study

\begin{tabular}{ccc}
\hline Diversity indices & $1968-1970$ & 1998 \\
\hline Number of species & 32 & 37 \\
H' & 3.145 & 3.229 \\
H' $^{\prime}{ }^{\prime}$ & 3.61 & 3.47 \\
J' & 0.87 & 0.93 \\
\hline
\end{tabular}

Table 4. Comparison of bird community indices in two study periods in diet and nesting category of guilds ( $\mathrm{S}$ - number of species, $\mathrm{N}$ - number of pair, $\mathrm{D}$ - density pairs/10 ha, F - frequency, B - biomass (kg/10 ha)

\begin{tabular}{|c|c|c|c|c|c|c|c|c|c|c|}
\hline \multirow{2}{*}{$\begin{array}{l}\text { Ecological } \\
\text { groups }\end{array}$} & \multicolumn{5}{|c|}{ years $1968-1970$} & \multicolumn{5}{|c|}{ year 1998} \\
\hline & S & $\mathrm{N}$ & $\mathrm{D}$ & $\mathrm{F}$ & B & $\mathrm{S}$ & $\mathrm{N}$ & $\mathrm{D}$ & $\mathrm{F}$ & $\mathrm{B}$ \\
\hline \multicolumn{11}{|c|}{ Nesting guilds } \\
\hline Ground nesters & 5 & 20 & 6.96 & 23.3 & 0.23 & 4 & 48 & 18.6 & 19.8 & 0.37 \\
\hline Shrub nesters & 3 & 8 & 2.79 & 2.3 & 0.11 & 7 & 33 & 11.4 & 13.5 & 0.74 \\
\hline Tree nesters & 11 & 29 & 10.1 & 33.7 & 2.00 & 13 & 66 & 24.9 & 27.0 & 4.94 \\
\hline Cavity nesters & 13 & 25 & 8.81 & 29.5 & 0.85 & 13 & 97 & 39.5 & 39.6 & 1.63 \\
\hline \multicolumn{11}{|c|}{ Habitat preferences } \\
\hline Edge & 13 & 39 & 13.7 & 45.3 & 1.66 & 10 & 35 & 12.2 & 14.2 & 1.82 \\
\hline Interior & 16 & 44 & 15.3 & 51.1 & 1.53 & 27 & 209 & 72.7 & 85.8 & 5.86 \\
\hline Other & 3 & 3 & 1.05 & 3.5 & 0.06 & - & - & - & - & - \\
\hline Total & 32 & 86 & 30.6 & 99.9 & 3.25 & 37 & 244 & 84.9 & 100.0 & 7.68 \\
\hline
\end{tabular}

The recorded increase in the number of species, index of diversity ( $\left.H^{\prime}\right)$, abundance and biomass of cavity and brush nester (Table 3,4) could be explained by progressive succession in plant community and stand age. In the first period of 
study $44.21 \%$ of the forest area in the reserve was covered with young tree plantations (trees up to 20 years old), 1.2\% of forest was in age classes of 40-60 years, and $38.48 \%$ of the forest area was covered with older Scots Pine stand of about 80 years, characterized by very simple vertical structure (the canopy top of Scots Pine crown and forest floor of mosses and lichens). In 1974 there was a tree clearance of 1.65 ha old Scots Pine stand and the area was immediately afforested by Scots Pine and birch. In the same year other open habitats (1.65 ha) in the western part of the reserve were also afforested. As a result the total forest area slightly increased. In the second period of study no tree stands below 20 years were recorded and some parts of forests were shifting towards older age classes of 80-100 years. Over $55 \%$ of the area of tree stand was in the age of $20-40$ years and about $15 \%$ in the age of 40-60 years. The advancing aging of tree stands and plant succession processes leaded to development of vertical structure, especially of an understorey layer.

\subsection{Mammals}

In the area of the reserve a total of 15 species of mammals were recorded. During two periods of removal of small mammals, a total of 12 specimens representing four species were obtained (Table 6) and 162 specimens of three bat species were caught. European Mole (Talpa europaea) was encountered in the whole area of the reserve, but only in the eastern part of the reserve was found in higher abundance. Common Shrew (Sorex araneus) was frequently recorded in the reserve and a total of three specimens were captured (Table 6). Pygmy Shrew (Sorex minutus) was recorded for the first time during the second period of investigation, when one specimen was captured. Also three species of bats were recorded for the first time: Daubenton's Bat (Myotis daubentonii) (159 specimens captured), Pond Bat (Myotis dasycneme) (two males captured) and Brown Long-eared Bat (Plecotus auritus) (one specimen captured). European Hare (Lepus europaeus) was noted in the reserve in late autumn and winter. Red Squirrel (Sciurus vulgaris) was observed several times over a year in various places in the reserve. Striped Field Mouse (Apodemus agrarius) was a common species in the alderwood association, two 
specimens were captured. Bank Vole (Myodes glareolus) was a very common species. Six specimens were captured in alderwoods and in pine forest habitats. Common Vole (Microtus arvalis) was recorded when a dead specimen was found at the road to the eastern bank of the watershed (September 1997). Least Weasel (Mustela nivalis) was recorded only once, when an individual was seen while crossing the eastern bank in October 1997. The occurrence of Red Fox (Vulpes vulpes) was confirmed by the records of its characteristic excrements over the whole area of the reserve for several times. Three specimens of Roe Deer (Capreolus capreolus) were seen in the southern island in October 1997. Wild Boar's (Sus scrofa) paw prints and rooted areas were noticed several times in the southern part of reserve and on islands in autumn 1997 and spring 1998.

Table 6. Comparison of sampling small mammals in 1968-1970 (BARTOSZ, MARKOWSKI 1972) and in 1997-1998 $\left(\mathrm{n}_{\mathrm{t}}\right.$ - number of trapnights, IP - index of trapability). Asterisk indicates records of dead individuals found in the study area

\begin{tabular}{lcccc}
\hline \multicolumn{1}{c}{ Species } & \multicolumn{2}{c}{$\begin{array}{c}1968-1970 \\
\left(\mathrm{n}_{\mathrm{t}}=725\right)\end{array}$} & \multicolumn{2}{c}{$\begin{array}{c}1997-1998 \\
\left(\mathrm{n}_{\mathrm{t}}=240\right)\end{array}$} \\
& $\mathrm{N}$ & $\mathrm{IP}$ & $\mathrm{N}$ & $\mathrm{IP}$ \\
\hline Sorex araneus & 5 & 0.007 & 3 & 0.012 \\
Sorex minutus & - & - & 1 & 0.004 \\
Apodemus agrarius & 3 & 0.004 & 2 & 0.008 \\
Myodes glareolus & 40 & 0.055 & 6 & 0.025 \\
Microtus oeconomus & 1 & 0.001 & - & - \\
Microtus arvalis & 6 & 0.008 & $1 *$ & - \\
Total & 55 & 0.076 & 12 & 0.05 \\
\hline
\end{tabular}

\section{DISCUSSION}

In comparison with the earlier study, there was no presence of Common Water Frog (Rana esculenta) and Pool Frog (Rana lessonae), which in 1968-1970 
were noted in the area of the reserve in very small numbers (Table 1). Low number of amphibians in the reserve was found in both periods of study. This phenomenon could be explained by the water temperature which fluctuates around $9^{\circ} \mathrm{C}$ and only in the southern canal water reaches $13-14^{\circ} \mathrm{C}$ (WoJTAS, SOSNOWSKI 1972). In consequence, some late reproducing species, such as pool frog, cannot lay their eggs frequently (TRANDA, CiCHOWICZ 1972). The scarcity of amphibians in the reserve could also be explained by the hydrotechnical works carried out in 1995, which disturbed the previous hydrological system. Increased discharge of cold water (during dredging activity) in all the canals might have forced scarce and scattered individuals of these species to emigrate. However, it is also possible that both species have disappeared much earlier, as a result of a marked decline in their population in the vicinity of the reserve caused by urbanization and disappearance of many shallow and periodic ponds. Remembering to treat these data carefully (they were collected without any formal quantitative method), it is possible to conclude that the abundance of anuran species decreased in this area by at least $50 \%$ over 30 years. This decline could be a result of developing built-up area of Ludwików housing estate on the right side of the Pilica River. Declines of amphibians caused by similar reasons were well documented on all continents where the group occurs (Barinaga 1990; Blaustein, Woke 1990; Blaustein et al. 1994) and the same process was so far recorded in Poland (GŁOWACIŃSKI et al. 1980; SURA, RYBACKI 1998).

Bird community changes during even-aged succession, especially following clearcutting or fire have been well documented in the literature along the $20^{\text {th }}$ century (KELLER et al. 2003). In general, two patterns of the changes were proposed, the first one suggested a linear and unimodal increase (ODUM 1950; HAAPANEN 1965; SHUGERT, JAMES 1973), and the second one a bimodal increase in avian richness during successions (GŁOWACIŃSKI 1981; DEGRAAF 1991; KELLER et al. 2003). Many authors have documented the relationship between vertical structure of plant community and bird species richness or composition (MACARTHUR, MACARTHUR 1961; CODY 1985). Increase in avian diversity along with the forest maturation was also frequently presented (JOHNSTON, ODUM 1956; EMLEN 1970; 
Shugart, JAMES 1973; Moss 1978; GŁOWACIŃSKI 1975, 1981; Helle, MONKKONEN 1990). JOKIMÄKI, HUHTA (1996) have shown that stand age is positively correlated with a tree volume and consequently with the productivity of forest areas. Therefore its effect on bird assemblages was suggested to be very strong. Primarily, abundance of cavity nesters is known to increase significantly with stand age, because of the greater availability of holes and crevices in mature trees (SMITH et al. 1985).

The processes of fauna synurbization occurring in the town of Tomaszów Mazowiecki are probably partially responsible for an increase in the abundance of such species as Blackbird, Starling, Eurasian Jay and Magpie. In 1994 the appearance of breeding tufted duck was recorded (SOSNOWSKI 1995). An abrupt increase in the abundance of this species was related to the process of synurbization, which was preceded by expansion of this species from the south-eastern Europe (HAgEMEIJer, Blair 1997; TOMiaŁojĆ, STAWARCZYK 2003) and its general increase in numbers across the geographical range. Similar reasons were suggested to be responsible for the appearance of Dunnock (Prunella modularis) and Thrush Nightingale (Luscinia luscinia) in the reserve (HAGEMEIJER, Blair 1997; TOMIAŁOJĆ, STAWARCZYK 2003).

The disappearance of the species connected with reeds as Great Reed Warbler (Acrocephalus arundinaceus) and Reed Warbler (Acrocephalus scirpaceus) occurred much earlier. In the course of the investigations in 1967-1970 period the number of pairs of reed warbler decreased from four to one (MARKOWSKI, WOJCIECHOWSKI 1972). This was related to the rapid reduction of the reed belt in the western part of the reserve and devastation of a small pond at the border of the reserve on the side of the Utrata Village. In consequence, these species did not occur in the reserve after 1971 (MARKOWSKI 1982). Untill the middle of the 1990s the Marsh Warbler (Acrocephalus palustris) persisted in the area (SOSNOWSKI 1995). There was, however, no conclusive evidence of breeding. The author mentioned also several other bird species breeding in the reserve in 1990s, i.e. Long-tailed Tit (Aegithalos caudatus), Bullfinch (Pyrrhula pyrrhula), Linnet (Carduelis cannabina), Tawny Owl (Strix aluco) and Turtle Dove (Streptopelia turtur) 
(SOSNOWSKI 1994, 1995). Thorough comparison of these two publications, the first of which is considered as a scientific research publication, while the latter a popularscientific monograph, brings numerous inconsistencies into light. This inevitably results in limited confidence put in these data. An example of contradictory information on the Water Rail (Rallus aquaticus) is that three breeding pairs occurred in the agrocoenoses of the Podoba district and in the Niebieskie Źródła Reserve (SOSNOWSKI 1994). By contrast, in the second publication the author did not mention the Water Rail, but the Common Moorhen (Gallinula chloropus) as a species breeding in the area (SOSNOWSKI 1995). SOSNOWSKI (1994) also mentioned two breeding pairs of Eurasian Coot (Fulica atra) in the reserve, while in the second publication (SOSNOWSKI 1995) he stated that the Eurasian Coot is a constant guest there and that clutches are produced by only solitary pairs and not every year. As the waters of the reserve are not abundant in submergent vegetation, it is difficult to imagine the breeding of as much as two pairs of coot. In fact some non-breeding Eurasian Coots were noted from September to the end of May (MARKOWSKI, WOJCIECHOWSKI 1972).

The changes in mammal species composition in comparison with the earlier investigations (BARTOSZ, MARKOWSKI 1972) included disappearance of two microtine species: Water Vole (Arvicola terrestris) and Root Vole (Microtus oeconomus) and the appearance of five others: Pygmy Shrew, Daubenton's Bat, Pond Bat, Brown Long-eared Bat and Wild Boar. Even during the former investigations Water Vole and Root Vole were rare, and their presence was indicated by only single observations of one swimming Water Vole and capturing a solitary specimen of Root Vole (Table 2). The retreat of Water Vole from the area of the reserve was possibly caused by hydrotechnical works that contributed to the eradication of reeds on the eastern bank and in the southern canal, which, in turn, limited food base of the species. The appearance of new mammal species could have different reasons. The appearance of Pygmy Shrew could be attributed to the process of succession and aging of tree stands. PUCEK (1984) stressed that the preferences of this species are confined to the mature deciduous or mixed forests and wet biotopes. A comparison of the results of the catches indicates large similarity of the 
composition of small terrestrial mammal species in both periods of study. Presence of three new bat species was recorded for the first time due to an application of a specific mist-net sampling method (HEJDUK et al. 1999). The presence of the Wild Boar in the reserve was an effect of an increase in the abundance and progressive synurbization of the populations inhabiting the area around Tomaszów Mazowiecki. The occurrence of wild boar within urban areas in Poland was noticed by MARKOWSKi et al. (1998) and MiKOs (2002) and was accompanied by a similar process in other European countries (FISCHER et al. 2002, SONZA 2000).

In conclusion, the increase in biodiversity of terrestrial vertebrate species of Niebieskie Źródła Nature Reserve was recorded, mainly in the bird (seven species) and mammal (five species) communities.

\section{REFERENCES}

BARINAGA, M. 1990. Where have all the froggies gone? Science 247: 1033-1034.

BenNetT, G. 1994. Conserving Europe's natural heritage: towards European ecological network. Graham and Trotman / Martinus Nijhoff.

Bartosz, G., Markowski, J. 1972. Fauna Niebieskich Źródeł. Materiały do fauny ssaków. Zesz. Nauk. Uniw. Łódz. Nauk. matem.- przyr., ser. II, 46: 97-98.

Blaustein, A.R., Woke, D.B. 1990. Declining amphibians: a global phenomenon? Trends Ecol. Evol. 5: 203-204.

Blaustein, A.R., WoKe, D.B., SousA, W.P. 1994. Amphibian declines: Judging stability, persistence and susceptibility of populations to local and global extinctions. Cons. Biol. 8: 60-71.

Borowiec, M., Stawarczyk, T., Witkowski, J. 1981. Próba uściślenia metod oceny liczebności ptaków wodnych. Not. Orn. 22: 45-61.

Cichowicz, M., ŻuchowskA, E. 1972. Fauna Niebieskich Źródeł. Robaki pasożytnicze płazów. Zeszyty Naukowe Uniwersytetu Łódzkiego. Nauki matematyczno-przyrodnicze, ser. II, 46: 5-11.

CoDy, M.L. 1985. Habitat selection in birds. Academic Press, London. 
DEGRAAF, R.M. 1991. Breeding bird assemblages in managed northern hardwood forest in New England. In: J.E. RoDIEK, E.G. BOLEN (eds), Wildlife and habitats in managed Landscapes. Island Press, Washington DC, pp. 153-171.

DiAMOND, J.M., MAY, R.M. 1977. Species turnover rates on islands: dependence on census interval. Science 197: 266-277.

EMLEN, J.T. 1970. Habitat selection by birds following a forest fire. Ecology 51: $343-345$.

EMneborg, H., Götmark, F. 2000. The role of threat to areas and initiative from actors for establishment of nature reserve in southern Sweden 1926-1996. Biodivers. Conserv. 9: 727-738.

Fischer, C., Gourdin, H., Doberman, M. 2002. Spatial behaviour of wild boar in Genova (Switzerland). Test in the methods and first results. Abstracts of the 4th International Wild Boar Symposium. Lousa Portugal, p. 25.

FORMANN, R.T.T. 1995. Some general principles of landscape and regional ecology. Landscape Ecol. 10: 135-142.

FULLER, R.J. 1995. Bird life of woodland and forest. Cambridge University Press, Cambridge.

GŁOWACIŃSKi Z. 1975. Succession of bird communities in the Niepołomice Forest (Southern Poland). Ekol. Pol. 23: 231-236.

GŁOWACIŃSKI, Z. 1981. Wtórna sukcesja ptaków w dojrzewającym ekosystemie leśnym. (Synteza). Studia Naturae A, 26: 1-64.

GŁowaciński, Z., Pieniek, M., Dyduch, A., Gertychowa, R., Jakubiec, Z., Kosior, A., ZEMANEK, M. 1980. Stan fauny kręgowców i wybranych bezkręgowców Polski - wykaz gatunków, ich występowanie, zagrożenie i status ochrony. Studia Naturae A, 21: 1-163.

GROMADZKI, M. 1970. Breeding bird communities of birds in mid-field afforested areas. Ekol. Pol. 18: 1-44.

HagemeiJer, W.J.M., Blair, M.J. 1997. The EBCC Atlas of European Breeding Birds. T, A D Poyser. London.

HAAPANEN, A. 1965. Bird fauna of the Finish forest in relation to forest succession. Ann. Zool. Fenn. 2: 153-196. 
Hejduk, J., Jaros, R., Pawenta, W., PŁuciennik, H. 1999. Charakterystyka jesiennego zgrupowania nocka rudego Myotis daubentonii w rezerwacie „Niebieskie Źródła” koło Tomaszowa Maz. XII O OKC, Błażejewko.

Helle, P., MÖNKKÖNEN, M. 1990. Forest succession and bird communities: theoretical aspects and practical implication. In: A. KEAST (ed.), Biogeography and Ecology of Forest Bird Communities. SPB. Academic Publishing, The Hague, pp. 299-318.

HUTCHESON, K. 1970. A test for comparing diversities based on the Shannon formula. J. Theor. Biol. 29: 151-154.

Johnston, D., Odum, E. 1956. Breeding bird populations in relation to plant succession on the Piedmont of Georgia. Ecology 37: 50-62.

JOKIMÄKI, J., HUHTA, E. 1996. Effects of landscape matrix anad habitat structure on a bird community in Northern Finland: a multiscale approach. Ornis Fenn. 73: 97-113.

Keller, J.K., Richmond, M.E., Smith, C.R. 2003. An explanation of patterns of breeding bird species richness and density following clearcutting in northeastern USA forests. Forest Ecol. Manag. 174: 541-564.

MacArthur, R.H., MacArthur, J.W. 1961. On bird species diversity. Ecology 42: 594-598.

Margules, C.R., Pressey, R.I. 2000. Systematic conservation planning. Nature 405: 243-253.

Markowski, J. 1982. Ptaki doliny Pilicy - projektowanej strefy krajobrazu chronionego. Ochrona Przyrody 44: 163-217.

MARKOwsKi, J., WoJCIECHOWSKI, Z. 1972. Fauna Niebieskich Źródeł. Materiały do awifauny rezerwatu i okolic. Zesz. Nauk. Uniw. Łódz. Nauk. matem.- przyr., ser. II, 46: 99-109.

Markowski, J., Wojciechowski, Z., KowalczyK, J.K., Tranda, E., Śliwiński, Z., SosZYŃSKI, B. 1998. Fauna Łodzi. Fundacja Człowiek i Środowisko, Łódź.

Moss, D. 1978. Diversity of woodland song-bird populations. J. Anim. Ecol. 47: $521-527$. 
Mowszowicz, J., OlACZEK, R. 1961. Flora naczyniowa rezerwatu „Niebieskie Źródła”. Łódzkie Towarzystwo Naukowe. Wydział III, 73, p. 40.

Mowszowicz J., OlaczeK, R. 1965. Niebieskie Źródła. Łódzkie Towarzystwo Naukowe. Łódź.

MiKOS, J. 2002. Management strategy of wild boar in Wejherowo-Gdańsk suburban area, North-Central Poland. Abstracts of the 4th International Wild Boar Symposium. Lousa Portugal, p. 28.

ODuM, E.P. 1950. Bird populations of the Highlands (North Carolina) Plateau region in relation to plant succession and avian invasion. Ecology 31: 587-605.

OlaczeK, R., Tranda, E. 1990. Z biegiem Pilicy. WP, Warszawa.

PuCEK, Z. 1984. Klucz do oznaczania ssaków Polski. PWN, Warszawa.

Rodrigues, A.S.L., Andelman, S.J., BAKarr, M.I., Boitani, L., Brooks, T.M., Cowlling, R.M., Fishrool, L.D.C., DA FonesCA, G.A.P., GASTON, K.J., Hoffman, M., Long, J.S., Marquet, P.A., Pilgrim, J.D., Pressey, R.L., Schipper, J., Sechrest, W., Stuart, S.N., Underhill, L.G., Waller, R.W., WATTS, M.E.J., YAN, X. 2004. Effectiveness of the global protected area network in representing species diversity. Nature 4128: 640-643.

ShUGART, H., JAmES, D. 1973. Ecological succession in Northwestern Arkansas. Auk 90: 62-77.

Smith, K.W., Averis, B., Martin, B. 1985. The breeding bird community of oak plantations in the forest of Dean, southern England. Acta Oecol.-Oec. Gen. 8: $209-217$.

SOKOŁOWSKI, J. 1972. Ptaki ziem polskich. PWN, Warszawa.

SonZA, B. 2000. Mamiferos urbanos en Zaragoza. Galemys 12: 55-57.

Sosnowski, J. 1994. Ptaki miasta Tomaszowa Mazowieckiego. Muzeum w Tomaszowie Mazowieckim, p. 44.

SoSNOWSKI, J. 1995. Niebieskie Źródła - Groty. Informator turystyczny. Tomaszów Mazowiecki. Urząd Miasta Tomaszowa Mazowieckiego.

SURA, P., RYBACKI, M. 1998. Losy polskich płazów. Wiedza i Życie 8: 38-39.

TABACKI, A. 1972. Fauna Niebieskich Źródeł. Widłonogi (Copepoda). Zesz. Nauk. Uniw. Łódz. Nauk. matem.- przyr. ser. II, 46: 15-19. 
TomaszewsKi, C. 1972. Fauna Niebieskich Źródeł Chruściki (Trichoptera). Zesz. Nauk. Uniw. Łódz. Nauk. matem.- przyr., ser. II, 46: 59-63.

TOMIAŁoJĆ, L. 1980. Kombinowana odmiana metody kartograficznej do liczenia ptaków lęgowych. Not. Orn. 21: 33-54.

Tomiałojć, L., StawarczyK, T. 2003. The avifauna of Poland. Distribution, numbers and trends. PPPP "proNatura", Wrocław. [In Polish with English summary].

Tomiałojć, L., WesoŁowski, T., Walankiewicz, W. 1981 Breeding bird community of a primaevel temperature forest (Białowieża National Park, Poland). Acta Ornithol. 20: 241-310.

TończyK, G., Klukowska, M., Jurasz, W., Markowski, J. 2000. The Niebieskie Źródła nature reserve as subject of scientific research. Acta Univ. Lodz., Folia Limnol. 7: 3-17.

Tranda, E., Cichowicz, M. 1972. Fauna Niebieskich Źródeł. Płazy (Amphibia). Zesz. Nauk. Uniw. Łódz. Nauk. matem.- przyr., ser. II, 46: 97-98.

Wojtas, F., Sosnowski, J. 1972. Fauna Niebieskich Źródeł. Wstęp. Zesz. Nauk. Uniw. Łódz. Nauk. matem.- przyr., ser. II, 46: 1-3.

WoJTAS, F., SoszYŃSKI, B. 1972. Fauna Niebieskich Źródeł. Bzygowate (Syrphidae, Diptera). Zesz. Nauk. Uniw. Łódz. Nauk. matem.- przyr., ser. II, 46: $75-80$.

WĘŻYK, M. 2008. Ochrona przyrody i krajobrazu. Raport o stanie środowiska w województwie łódzkim w 2007 roku. Wojewódzki Inspektorat Ochrony Środowiska. Łódź, pp. 203-209. 